\title{
Anti-CD7 Monoclonal Antibody
}

National Cancer Institute

\section{Source}

National Cancer Institute. Anti-CD7 Monoclonal Antibody. NCI Thesaurus. Code C112887.

Any monoclonal antibody directed ag ainst the cell surface glycoprotein CD7, regardless of the antibody type. 